\title{
Equilibrium
}

Quarterly Journal of Economics and Economic Policy

VOLUME 7 ISSUE 2, 2012

ISSN $1689-765 \mathrm{X}$

\section{Crisis Caused Changes IN INTRINSIC LIQUIDITY VALUE IN Non-Profit InSTITUTIONS**}

JEL Classification Codes: G31, L31, M21

Keywords: Intrinsic liquidity value, Non-profit financial management, financial liquidity

\begin{abstract}
Liquid assets which non-profit institutions hold are not a source of any special interests and although the close to cash assets together with credit lines available for non-profit institution are connected with resigning from realizing a part of income or costs, non-profit institutions decide to hold some liquidity reserves. This results not only from transactional needs, but also from precautional and speculative reasons. Investment in liquid reserves resulting from speculative demand for money may be assessed by usage of capital budgeting methods. In the paper, each of these aspects of liquidity was taken into consideration and presented from non-profit perspective. Non-profit liquidity value determination may often significantly contribute to the solution of working capital management problems in these institutions.
\end{abstract}

(C) Copyright Nicolaus Copernicus University Press

Date of Submission: May 2, 2011; date of acceptance: May 23, 2012

* Contact: e-mail: Grzegorz.Michalski@ue.wroc.pl, Uniwersytet Ekonomiczny we Wrocławiu, Komandorska 118/120, p.Z-2, KFPiZW, 53-345 Wrocław, Poland

** Acknowledgment. The research is financed from the Polish science budget resources in the years 2010-2012 as the research project NN113021139. 


\section{INTRODUCTION}

Social economy institutions can work as taxed commercial businesses or as non-taxed non-profit institutions (Michalski 2011; Lane et all 2001, pp. 1-7). The advantage of commercially driven institutions is that they are more effectively managed than government-controlled ones (Nowicki 2004, p. 29). In this paper, the non-profit institution liquidity management model is analyzed. It is done in the context of three basic different situations by comparison of: non-taxed government controlled institution, non-taxed non-profit institution and taxed commercially managed business (Berger 2008, pp. 4647). The more difficult economic situation after the crisis causes many nonprofit institutions to face, on the one hand, smaller cash inflows and financing possibilities and, on the other hand, higher demand on their services. After the crisis, those institutions face specific incumbent needs, which are the result of higher unemployment and other similar factors (Zietlow 2010, pp. 238-248).

Non-profit institutions differ from a for-profit institutions, because their basic aim, is not the maximization of an institution value, but the best realization of its mission (Zietlow, Hankin, Seidner 2007, pp. 6-7). However, for the assessment of financial decision of a non-profit institution, analogous rules should be used to the ones used for for-profit institutions (Brigham, Gapenski 2000, pp. 524-536). The rules teach that the higher the risk, the higher cost of capital rate should be used to evaluate the future results of current decision. Of course, it is also positively linked to the level of efficiency and effectiveness in realization of the mission of a non-profit institution. The cost of financing net liquid assets (working capital) depends on the risk included to the institution strategy of financing and/or investment in liquidity.

The value which could be attributed to liquidity for non-profit institution depends on the current liquidity needs of a non-profit institution. Managing teams in non-profit institutions have a lot of important reasons why their institution should possess some high liquid resources reserves, even if a current interest rate is positive (Kim 1998). The reasons can be classified into three main groups: (1) transactional reason as the result of the necessity of current expenses financing, (2) precautional reason as the result of fear of future cash flows uncertainty, (3) so called speculative reason, as the result of the future interest rate level uncertainty.

Liquid assets like money resources in an institution's safe is not a source of any or little interests. Maintaining liquidity reserve in a non-profit institution is a result of the belief that the value of lost income on the account of interest will be compensated for by the benefits for the incumbents of a nonprofit institution (Kim 1998; Lee 1990). The hypothetical benefits are con- 
nected with the greater probability of an institution's mission to be completed, thanks to adequate liquidity level. Then, the institutions maintaining such reserves assume that in equilibrium conditions, marginal liquidity value is equal to the interest rate of the Treasury Bonds investments (or interest rate being a cost of short-term credit we took out to obtain liquidity. Without doubt, the statement that liquidity does not bring any benefits may be rejected at once. From such a perspective, liquidity would be treated as a "necessary evil", linked only to the costs resulting from interests lost. Another incorrect conclusion would be an assumption that present net value always equals zero. It would be a result of the statement that due to the fact that marginal liquidity value is always equal to interests lost, the amount of cash reserves has no significance at all (Henderson 1989, p. 95; Kim 1998, Lee 1990, p. 540).

For an institution being in possession of liquid reserves, the marginal utility of liquidity changes. Along with the growth in amount of cash possessed, the marginal cash value decreases. So, it may be noticed that for the market Treasury Bond rate or short-term credit rate, it pays to keep some money in reserve only to the specific level. There is a point corresponding with the optimal (critical) liquidity level, up to which the amount of liquid assets in the non-profit institution may be increased at a profit (Washam 1989, p. 28; Henderson 1989, Lee 1990). The term: liquidity degree (or level) is connected with the concept of "liquidity container" known from economic literature. The more liquid assets (which may be easily convertible into known amount of money resources and sensible only to a slight value change risk), the higher non-profit institution's liquidity level.

After crossing this critical liquidity level, the Treasury Bonds sale or taking out a short-term debt is unprofitable for a non-profit institution. The marginal benefit from higher cash reserve is lower than the cost of interests lost (Rast 2000; Washam 1989; Henderson 1989).

\section{NON-PROFIT INSTITUTIONS LIQUIDITY DEFINITION}

In economic literature, liquidity is defined in many various ways. It is understood as an non-profit institution solvency i.e. ability to regulate its obligations which result from usual transactions, unexpected events or situations enabling "bargain" purchase of goods (Henderson 1989; Lee 1990). On the other hand, liquidity is considered as a transaction space on the financial market. It occurs when there is a "liberty" of carrying out "huge" sale or purchase transactions on the market, with no fear that you will not find appropriate demand or supply. Another popular definition of liquidity is de- 
scribing it as assets' convertibility into other assets. In other words, liquidity is an easiness of carrying out the exchange transactions with low transaction costs.

There are important connections among these three looks on liquidity. If there appears the necessity of regulating an obligation exceeding cash reserves in non-profit institution possession, the possibility of repayment depends on whether it is possible to exchange the assets possessed for cash or not. If so, it will be paid off on time. At the same time, the possibility of such an exchange depends on the capacity of a non-profit institution's assets market. It means that the ability to regulate non-profit institution's obligations (short-term solvency) is dependent on the capacity of the market of assets constituting non-profit institution's reserves (or more generally: its property). Financial liquidity is therefore an internal category of a non-profit institution, influenced both by the managing team and other factors occurring inside a non-profit institution or in its surroundings. The long-term liquidity is totally disregarded here (Washam 1989; Henderson 1989; Lee 1990).

We will understand non-profit institution's financial liquidity as liquid assets reserve, which may be used in order to carry out transaction without any time or financial loss resulting from normal operational activity (transactional liquidity) or because of unexpected needs (precautional liquidity) or because of attractive profit opportunities expectations (speculative liquidity) (Washam 1989; Beck 1993; Lee 1990).

The non-profit institution transactional and precautional liquidities on sufficient level enable prompt fulfillment of internal (salary payments etc.) and external creditors (suppliers payment etc.). A non-profit institution's financial liquidity (operational and precautional) usually concerns operational activity and is not linked to investment activity. If it comes to enfeeblement or loss of operational and precautional liquidity in a non-profit institution, it causes a threat of (Scherr 1989; Washam 1989; Beck 1993): (a) lowering decision making elasticity, (b) deteriorating non-profit institution ability to set the institution mission, (c) higher foreign capital raising cost, (d) demobilization of donors, (e) worsening non-profit institution position.

In order to avoid such dangers, constant monitoring of non-profit institutions' financial liquidity is necessary, and then taking actions to ensure its economic-financial equilibrium.

\section{OPTION VALUE OF LIQUIDITY IN NON-PROFIT INSTITUTIONS}

Liquid resources resulting from the "speculative" liquidity demand may bring some benefits, but do not have to. As we can see, liquidity exceeding 
the everyday transactions demand, provides a non-profit institution with the option to take up unexpected projects worth realization to better realization of the mission (Washam 1989; Beck 1993). Keeping an access to liquidity which exceeds transactional needs, a non-profit institution is in possession of call option.

If in the period when the non-profit institution possesses speculative liquidity sources there appears a possibility of purchasing assets whose normal long-term value amounts to 8 thousand euros and at the given moment, they can be purchased for 3 thousand euros, the NPV of such a "project" will come to 5 thousand euros. If non-profit institution possesses the required money reserves, it will have benefit of 5 thousand euros. If a non-profit institution does not have the access to additional liquidity - it will lose the possibility of investment project realization together with 5 thousand euros. Typical options have a value equal to the assets' value reduced by the price of realization and option price. If the purchased assets' value exceeds the sum of those two quantities, speculative liquidity reserves generates profits equal to NPV of the project taken. It concerns the situation in which speculative reserves are used, i.e. when operational net cash flows is not sufficient to cover the costs resulting from taking up the investment (Scherr 1989; Washam 1989; Beck 1993). In other cases, there is no profit from additional liquidity resources coming from speculative demand.

Option liquidity value is dependent on 6 factors (Beck 1993). The first of them is the present net value project value. If the potential project profitability increases, the value of a project taking option will increase as well. Another factor determining liquidity value is a non-profit institution's cash flow. If other factors are constant, option value will increase along with the decrease of operational cash flows level, and will fall together with the increase of those flows level.

It is because, along with increased operational cash flow level, of the probability that the unexpected investment project cost will be covered with those flows increases too. Therefore, the probability of using additional liquidity linked to speculative demand is decreased. The third and the forth factor determining option liquidity value is the cash flows and project cost changeability.

If the changeability of operational cash flows increases, we are faced with a lower probability of using additional speculative liquidity - and therefore the option liquidity value decreases. The probability of using additional liquidity decreases along with the increase in the changeability of the project cost. Such increase in changeability is also accompanied by diminishing project profitability.

Other factors influencing the option liquidity value are: interest rate and the correlation between operational cash flows and costs. If the interest rate 
increases, the present project value will decrease, and then - the option liquidity value will decrease as well. However, the correlation between operational cash flows and costs is quite different. If this correlation increases, option liquidity value will increase too. It results from the fact that the probability of using some operational cash flows to take up the investment, omitting liquid speculative reserves, will be decreased then (Hill 1995; Puxty 1992).

\section{NON-PROFIT INSTITUTIONS OPTIMAL LIQUIDITY LEVEL FIXED ON THE BASIS OF THE CONCEPT OF VALUE OF LIQUIDITY}

Increasing liquidity level makes sense only to a specific optimal quantity (Michalski 2011b). It results from the current market liquidity value (shortterm deposit interest rate or short-term credit interest rate available for a nonprofit institution). The point to which non-profit institution liquidity level may be increased at a benefits for incumbents of the non-profit institution, results from equalizing of market liquidity value and internal non-profit institution liquidity value (i.e. for $v_{m}=v_{i}$ ):

$$
V_{i}\left(p p_{o p t}\right)=v_{m}
$$

where:

$\mathrm{V}_{\mathrm{i}}\left(p p_{\text {opt }}\right)$ - internal liquidity value corresponding to the optimal non-profit institution financial liquidity value.

After crossing his optimal liquidity level $\left(p p_{o p t}\right)$, increased liquidity (e.g. by abandoning to deposit the resources and/or liquidation of existing deposits, or taking short-term debt) is uneconomic for a non-profit institution. This unprofitability, among other things, results from the fact that marginal utility of higher financial liquidity level is lower than the cost of lost interests benefits. The cost arises as a result of the loss of open deposit interest linked profits in case of resignation from depositing the sources or unnecessarily incurred financial costs if the non-profit institution uses "unnecessary" outside financing. Optimal financial liquidity level $\left(p p_{o p t}\right)$ is a result of comparing the market liquidity level $v_{m}$, available for a non-profit institution and the internal liquidity value $v_{i}\left(p p_{o p t}\right)$.

The following conditions are implied by these fact: carrying out investment 2., taking up the credit 3., and equilibrium 4. 
carrying out investment condition: $v_{i}<v_{m}$

taking up the credit condition: $v_{i}>v_{m}$

equilibrium condition (optimal liquidity level): $v_{i}=v_{m}$,

where:

$v_{i}$ - internal financial liquidity value in a non-profit institution,

$v_{m}$ - market financial liquidity value (available for a non-profit institution).

Example: A non-profit institution has a short-term credit at a bank at its disposal. $v_{m}$ is the cost of this credit. If a non-profit institution's management estimates that the internal liquidity value amounts to: $v_{i}$, it will delay taking the credit until the internal liquidity value $v_{i}$ is higher than the market value $v_{m}$. When these two values become equal, a non-profit institution's financial liquidity value will reach the optimal value. But when $v_{i}$ exceeds the $v_{m}$ level, a non-profit institution will require external financing.

Current finance management begins with determining the optimal liquidity level, because it guarantees the best effects (McMenamin 1999). In order to determine this level, the information abort internal liquidity value is needed (abort the course of the curve representing it), and non-profit institution market liquidity value must be known too.

Financing of the liquidity has its cost depending on risk linked with liquidity strategies used by the financed institution. If we have higher risk, we will have higher cost of financing (the cost of capital) and, as a result, other financially measured effects on a non-profit institution.

The cost of financing of liquidity depends on the kind of financing, next on the level of liquidity in relation to sales and, last but not least, the danger for a non-profit institution's mission caused by risk exposition.

When choosing between various levels of liquidity in relation to sales, we use one from three strategies: (RES) restrictive strategy, when for the realization of the mission of a non-profit institution we use the most risky but the cheapest, the smallest possible level of liquidity, (MOD) moderate strategy when for the realization of the mission of non-profit institution we moderate between risk and costs of holding liquidity, and (FLX) flexible strategy, when for the realization of the mission of non-profit institution we use the most expensive and rather high levels of working capital aiming to protect a non-profit institution from the risk of shortage of liquidity. 
Exposition to the risk depends on the kind of mission realized by a nonprofit institution. If the risk exposition should be higher, then it is smarter to choose more flexible and more conservative solutions, in order to have better results. It also works in the opposite direction. The safer mission realized by a non-profit institution, the more restrictive and more aggressive strategies give better results.

A non-profit institution's property consists of total assets, i.e. fixed assets and current assets, known also as liquid assets. We can see that property as fixed capital and working capital as well. Generally, working capital equal to current assets is defined as a sum of inventory, short term receivables (including all the accounts receivable for deliveries and services regardless of the maturity date) and short-term investments (cash and its equivalents) as well as short-term prepaid expenses (Mueller 1953; Graber 1948; Khoury 1999; Cote 1999). Money tied in liquid assets serve non-profit institution as protection against risk (Merton 1999, p. 506; Lofthouse 2005; pp. 27-28; Parrino 2008, pp. 224-233, Poteshman 2005, pp. 21-60), but this money is also considered as an investment. It is because a non-profit institution resigns from instant utilization of resources for the realization of the mission for the sake of possible future benefits, which could be used for future realization of the mission (Levy 1999, p. 6; Reilly 1992, p. 6; Fabozzi 1999, p. 214).

The level of liquid assets is the effect of processes linked to the production institution or services realization (Nita 2011). So, it results from the processes which are operational by nature, and therefore correspond to the willingness to produce on time the services which are probably desired by final incumbents of the institution's mission (Michalski 2012; Baumol 1952; Beck 2005; Beranek 1963; Emery 1988; Gallinger 1986; Holmstrom 2001; Kim 1998; Kim 1978; Lyn 1996; Tobin 1958; Stone 1972; Miller 1966; Miller 1996; Myers 1998; Opler 1999). It exerts influence mainly on the inventory level and belongs to the area of interest of operational management (Michalski 2011c; Peterson 1979, pp. 67-69; Orlicky 1975, pp.17-19; Plossl 1985, pp. 421-424). Nevertheless, current assets are also the result of active customer winning and maintaining policy (Bougheas 2009). Such policy is executed by finding an offer and a specific market where the product or service is sold. The consequences of this policy are reflected in the final product's inventory level and the accounts receivable in short term.

Among the motivating factors for investing in current assets, one may also mention uncertainty and risk. Due to uncertainty and risk, it is necessary to stock up circumspect (cautionary) cash, material and resources reserves which are inevitable in maintaining the continuity of production and preparing final services needed for the realization of the mission of a non-profit institution. 
Many institutions could act in a fast changing environment where the prices of needed materials and resources are subject to constant change. Other factors - like exchange rates for instance, are very changeable, too. It justifies keeping additional cash sources allotted for realization of built-in call options (American type) by buying the raw materials more cheap than the long term expected equilibrium price would suggest.

Non-profit institutions' relationships with suppliers of materials, resources and services which are necessary to produce and sell final products usually result in adjourning the payments. Such situation creates accounts payable and employees (who are to some extent internal services providers). We will call such categories of obligations non-financial current obligations, in order to differentiate between them and the current obligations which result from taking on financial obligations, e.g. short term debt.

Postponing required payments exerts impact on reducing the demand for those non-profit institution's resources which are engaged in current asset financing. The current assets reduced by non-financial current obligations (non-financial short term obligations) are called net current assets. Net current assets are the resources invested by a company in current assets, equated with the capital tied in these assets.

\section{WORKING CAPITAL INVESTMENT STRATEGIES AND NON-PROFIT INSTITUTION EFFICIENCY}

Next, it is necessary to consider the influence of each strategy of investment in the liquidity on the rate of cost of capital financing non-profit institution and that influence on the its economic results.

In the first variant, one must assume that capital providers (lenders) seriously consider while defining their claims to rates of return the liquidity investment strategy chosen by the institution they invested in. Let us also assume that the correction SZ function graph connected with strategy choice could be even and linear (Figure 1).

SZ1 variant. Capital providers take into consideration a non-profit institution's liquidity investment strategy while defining their claims rrgarding the rates of return. The restrictive strategy is perceived as more risky, and therefore, depending on investors' risk aversion level, they tend to ascribe an additional expected risk premium to the financed non-profit institution applying restrictive strategy. To put it simply, let us assume that ascribing the additional risk premium for applied liquidity investment strategy is reflected in the value of $\beta$ risk coefficient. For each strategy, the $\beta$ risk coefficient 
will be corrected by the corrective coefficient SZ corresponding to that specific strategy in relation to the CA/CR situation.

Figure 1. Hypothetical shapes of line of correction $S Z$ as the function of CA/CR in the SZ1 variant
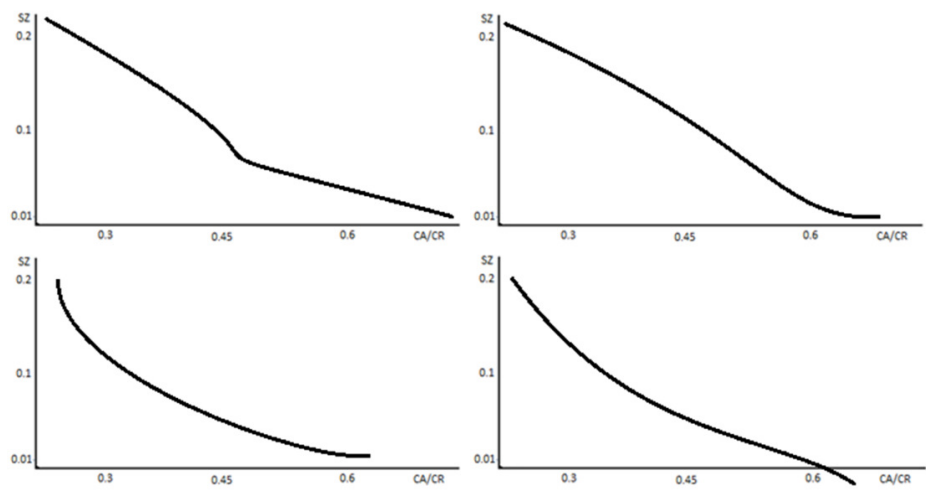

Source: hypothetical data.

The basic risk free rate is $4,5 \%$, and the rate of return on market portfolio is $10 \%$. If an analyzed non-profit institution is a representative of the sector for which the non-leveraged risk coefficient $\beta_{u}=0,6$, then on the basis of so called Hamada relation, we can estimate the equity cost rate which is financing that institution in case of each of the three strategies in the SZ1 variant.

$$
\beta_{l}=\beta_{u} \times\left(1+(1-T) \times \frac{D}{E}\right)=0,6 \times\left(1+0,81 \times \frac{0,4}{0,6}\right)=0,924,
$$

where:

$T$ - effective tax rate ${ }^{1}, D$ - institution financing capital coming from creditors (a sum of short term debt and long term debt $\left.D=D_{s}+D_{l}\right), E$ - institution financing capital coming from founders / owners of the institution, $\beta$ - risk coefficient, $\beta_{u}$ - risk coefficient for an assets of a non-profit institution which does not use debt, $\beta_{l}-$ risk

${ }^{1}$ According to (Brigham 2000) even non-profit corporations which are exempt from taxation, and have the right to issue tax-exempt debt, but individual contributions to these nonprofit organizations can be deducted from taxable income by the donor, so: "non-profit businesses have access to tax-advantaged contributed capital”. 
coefficient for an institution which applies the system of financing by creditors capital (here we have both asset and financial risk).

For each individual strategy, where CA/CR is 0,3 or 0,45 or 0,6 ; the $\mathrm{SZ}$ risk premium is 0,2 or ), 1 or 0,01 :

$$
\beta_{l_{\ldots}}^{*}=\beta_{u} \times\left(1+(1-T) \times \frac{D}{E}\right) \times(1+S Z)
$$

where:

$S Z$ - risk premium correction dependent on the liquidity investment strategy.

Using that information, the calculation of the cost of equity rates for each liquidity investment strategy is possible:

$$
k_{e_{\ldots}}=\beta_{l} \times\left(k_{m}-k_{R F}\right)+k_{R F}
$$

where:

$k$ - the rate of return expected by capital donors, and at the same time (from nonprofit institution perspective) - the cost of financing capital rate, $k_{e}$ - for cost rate of the equity, $k_{d l}$ - for long term debt rate, $k_{d s}$ - for short term debt rate, $k_{m}$ - for average rate of return on typical investment on the market, $k_{R F}$ - for risk free rate of return whose approximation is an average profitability of treasury bills in the country where the investment is made.

In a similar way, we can calculate the risk premiums for alternative rates. Next, it is possible to calculate the risk premiums for alternative cost of short term rates. As a result, the cost of capital rate will amount to:

$$
\begin{gathered}
C C=\frac{E}{E+D_{l}+D_{s}} \times k_{e}+\frac{D_{l}}{E+D_{l}+D_{s}} \times k_{d l} \times(1-T)+\frac{D_{s}}{E+D_{l}+D_{s}} \\
\times k_{d s} \times(1-T)
\end{gathered}
$$

However, for each strategy, this cost rate will be on a different level (calculations in the Table 1).

As it is shown in the table, the rates of the cost of capital financing the non-profit institution are different for different approaches to liquidity investment. The lowest rate: $\mathrm{CC}=7,9 \%$; is observed in the flexible strategy, because that strategy is linked with the smallest level of risk, but the highest economic effect is linked with restrictive strategy of investment in liquidity, but the best result is for restrictive strategy: 7312 . 
Table 1. The cost of capital and changes in economic results depending on the choice of liquidity investment strategy (before the crisis influence)

\begin{tabular}{|c|c|c|c|c|c|}
\hline Liquidity investment strategy & RES & $\Delta$ & MOD & $\Delta$ & FLX \\
\hline Cash Revenues (CR) & 1500 & $\pi$ & 1560 & $\pi$ & 1607 \\
\hline Fixed assets (FA) & 1200 & $\pi$ & 1238 & $\nearrow$ & 1268 \\
\hline Current assets (CA) & 450 & $\nearrow$ & 702 & $\nearrow$ & 964 \\
\hline Total assets $(\mathrm{TA})=$ Total liabilities $(\mathrm{TL})$ & 1650 & $\nearrow$ & 1940 & $\nearrow$ & 2232 \\
\hline Accounts payable (AP) & 225 & $\nearrow$ & 351 & $\nearrow$ & 482 \\
\hline Capital invested $\left(E+D_{1}+D_{s}\right)$ & 1425 & $\pi$ & 1589 & $\pi$ & 1750 \\
\hline Equity (E) & 855 & $\nearrow$ & 954 & $\nearrow$ & 1050 \\
\hline Long-term debt $\left(D_{1}\right)$ & 285 & $\lambda$ & 318 & $\nearrow$ & 350 \\
\hline Short-term debt $\left(D_{s}\right)$ & 285 & $\nearrow$ & 318 & $\nearrow$ & 350 \\
\hline EBIT share in CR & 0,5 & $\searrow$ & 0,45 & $\searrow$ & 0,40 \\
\hline Earnings before interests and taxes (EBIT) ${ }^{2}$ & 750 & $\searrow$ & 702 & $\searrow$ & 643 \\
\hline Free Cash Flows in 1 to $\mathrm{n}$ periods $\left(\mathrm{FCF}_{1 . . \mathrm{n}}\right)$ & 750 & $\searrow$ & 702 & $\searrow$ & 643 \\
\hline Initial Free Cash Flows in year $0\left(\mathrm{FCF}_{\mathrm{o}}\right)$ & -1425 & $\searrow$ & -1589 & $\searrow$ & -1750 \\
\hline SZ risk premium correction & 0,2 & $\searrow$ & 0,1 & $\searrow$ & 0,01 \\
\hline Leveraged and corrected risk coefficient $\beta_{l}$ & 1,1 & $\searrow$ & 1,02 & $\searrow$ & 0,93 \\
\hline Cost of equity rate $\left(\mathrm{k}_{\mathrm{e}}\right)$ & $10,6 \%$ & $\searrow$ & $10,1 \%$ & $\searrow$ & $9,6 \%$ \\
\hline Long-term debt rate $\left(\mathrm{k}_{\mathrm{dl}}\right)$ & $7,2 \%$ & $\searrow$ & $6,9 \%$ & $\searrow$ & $6,7 \%$ \\
\hline Short-term debt rate $\left(\mathrm{k}_{\mathrm{ds}}\right)$ & $6,5 \%$ & $\searrow$ & $6,4 \%$ & $\searrow$ & $6,2 \%$ \\
\hline Cost of capital (CC) & $8,6 \%$ & $\searrow$ & $8,2 \%$ & $\searrow$ & $7,9 \%$ \\
\hline Economic result of liquidity strategy & 7312 & $\searrow$ & 6967 & $\searrow$ & 6422 \\
\hline
\end{tabular}

Source: hypothetical data.

The expected after-crisis changes will correct both the market liquidity value and the cost of capital rate. Both factors influence the target's (and optimal) liquidity level for a non-profit institution. That will result in more restrictive liquidity levels because of the change in equilibrium point for intrinsic and market liquidity values (Michalski 2010, pp. 86-88; GolawskaWitkowska et all 2006, p. 144; Jaworski, 2010, pp. 366-368). The cost of capital will be higher after crisis than before (Fernandez et all 2011, pp. 4-7, Fernandez, Campo, 2010, pp. 4-7, Fernandez 2008, pp. 5-8). That will result

\footnotetext{
${ }^{2}$ Because of exempt of taxation, EBIT is equal to net operating profit after taxes (NOPAT).
} 
in changes in efficiency of liquidity policy for non-profit institutions (as shown in Table 2).

Table 2. The cost of capital and changes in economic results depending on the choice of liquidity investment strategy (after the crisis influence)

\begin{tabular}{|c|c|c|c|c|c|}
\hline Liquidity investment strategy & RES & $\Delta$ & MOD & $\Delta$ & FLX \\
\hline Cash Revenues (CR) & 1400 & $\lambda$ & 1456 & $\pi$ & 1500 \\
\hline Fixed assets (FA) & 1120 & $\nearrow$ & 1156 & $\nearrow$ & 1184 \\
\hline Current assets (CA) & 420 & $\lambda$ & 655 & $\nearrow$ & 900 \\
\hline Total assets $(\mathrm{TA})=$ Total liabilities $(\mathrm{TL})$ & 1540 & $\pi$ & 1811 & $\nearrow$ & 2083 \\
\hline Accounts payable (AP) & 210 & $\nearrow$ & 328 & $\nearrow$ & 450 \\
\hline Capital invested $\left(E+D_{1}+D_{s}\right)$ & 1330 & $\lambda$ & 1483 & $\pi$ & 1634 \\
\hline Equity $(\mathrm{E})$ & 798 & $\nearrow$ & 890 & $\nearrow$ & 980 \\
\hline Long-term debt $\left(D_{1}\right)$ & 266 & $\lambda$ & 297 & $\nearrow$ & 327 \\
\hline Short-term debt $\left(D_{s}\right)$ & 266 & $\nearrow$ & 297 & $\nearrow$ & 327 \\
\hline EBIT share in CR & 0,5 & $\searrow$ & 0,45 & $\searrow$ & 0,40 \\
\hline Earnings before interests and taxes (EBIT) & 700 & $\searrow$ & 655 & 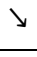 & 600 \\
\hline Free Cash Flows in 1 to $n$ periods $\left(\mathrm{FCF}_{1 . . \mathrm{n}}\right)$ & 700 & $\searrow$ & 655 & $\searrow$ & 600 \\
\hline Initial Free Cash Flows in year $0\left(\mathrm{FCF}_{\mathrm{o}}\right)$ & -1330 & $\searrow$ & -1483 & $\searrow$ & -1634 \\
\hline SZ risk premium correction & 0,2 & $\searrow$ & 0,1 & 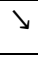 & 0,01 \\
\hline Leveraged and corrected risk coefficient $\beta_{l}$ & 1,1 & $\searrow$ & 1 & $\downarrow$ & 0,93 \\
\hline Cost of equity rate $\left(\mathrm{k}_{\mathrm{e}}\right)$ & $21,6 \%$ & $\searrow$ & $20,3 \%$ & $\searrow$ & $19 \%$ \\
\hline Long-term debt rate $\left(\mathrm{k}_{\mathrm{dl}}\right)$ & $15,2 \%$ & $\searrow$ & $14,2 \%$ & $\searrow$ & $13,3 \%$ \\
\hline Short-term debt rate $\left(\mathrm{k}_{\mathrm{ds}}\right)$ & $13,2 \%$ & $\searrow$ & $12,5 \%$ & $\searrow$ & $11,9 \%$ \\
\hline Cost of capital (CC) & $17,6 \%$ & $\searrow$ & $16,5 \%$ & 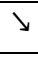 & $15,5 \%$ \\
\hline Economic result of liq & 2650 & $\searrow$ & 2494 & $\searrow$ & 2244 \\
\hline
\end{tabular}

Source: hypothetical data.

As it is shown in table 2, the after-crisis changes influence the efficiency of the liquidity investment of non-profit institution. Of course, that change depends on a non-profit institution's risk sensitivity. Depending on their risk sensitivity, an additional risk premium for a non-profit institution which implemented this type of strategy should be used. As presented on Figure 2, we have stronger risk sensitivity than in the previous situation. 
Figure 2. Hypothetical shapes of line of correction $\mathrm{SZ}$ as a function of $\mathrm{CA} / \mathrm{CR}$ in the SZ2 variant
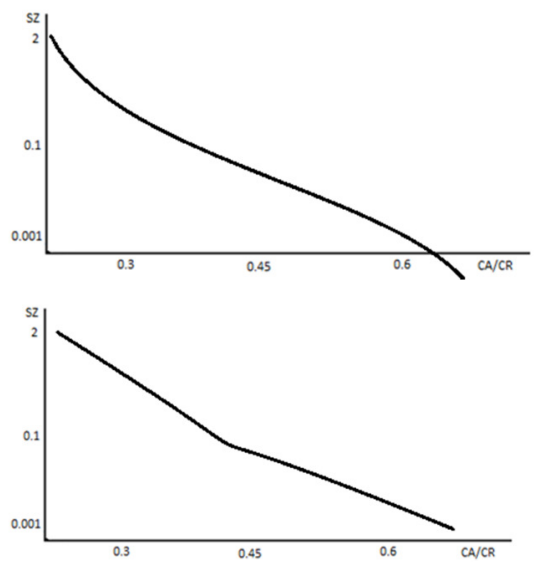
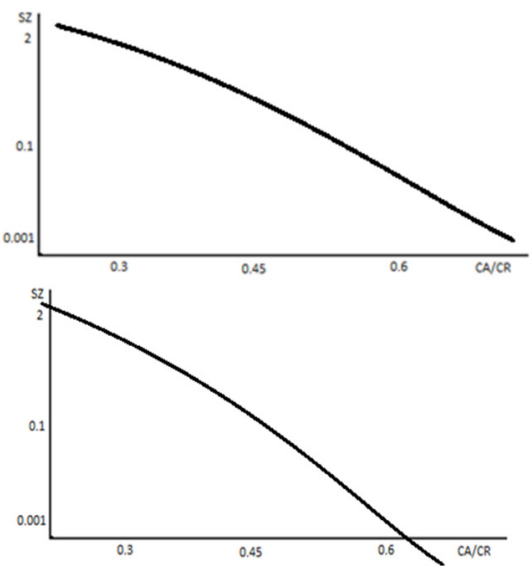

Source: hypothetical data.

In the Table 3. There are calculations for that variant. For each strategy the cost of capital rate $C C$ will be on a different level.

Table 3. Cost of capital and changes in economic results depending on the choice of liquidity investment strategy (before the crisis influence)

\begin{tabular}{|l|r|r|r|}
\hline \multicolumn{1}{|c|}{ Liquidity investment strategy } & RES & MOD & FLX \\
\hline Cash Revenues (CR) & 1500 & 1560 & 1607 \\
\hline Fixed assets (FA) & 1200 & 1238 & 1268 \\
\hline Current assets (CA) & 450 & 702 & 964 \\
\hline Total assets (TA) = Total liabilities (TL) & 1650 & 1940 & 2232 \\
\hline Accounts payable (AP) & 225 & 351 & 482 \\
\hline Capital invested (E+D $+\mathrm{D}_{\mathrm{s}}$ ) & 1425 & 1589 & 1750 \\
\hline Equity (E) & 855 & 954 & 1050 \\
\hline Long-term debt $\left(\mathrm{D}_{1}\right)$ & 285 & 318 & 350 \\
\hline Short-term debt $\left(\mathrm{D}_{\mathrm{s}}\right)$ & 285 & 318 & 350 \\
\hline EBIT share in CR & 0,5 & 0,45 & 0,4 \\
\hline Earnings before interests and taxes $(\mathrm{EBIT})$ & 750 & 702 & 643 \\
\hline Free Cash Flows in 1 to n periods $\left(\mathrm{FCF}_{1 . . \mathrm{n}}\right)$ & 750 & 702 & 643 \\
\hline
\end{tabular}


Table 3 Continued

\begin{tabular}{|l|r|r|c|}
\hline \multicolumn{1}{|c|}{ Liquidity investment strategy } & RES & MOD & FLX \\
\hline Initial Free Cash Flows in year $0\left(\mathrm{FCF}_{\mathrm{o}}\right)$ & -1425 & -1589 & -1750 \\
\hline SZ risk premium correction & 2 & 0,1 & 0,001 \\
\hline Leveraged and corrected risk coefficient $\beta_{l}$ & 2,8 & 1 & 0,93 \\
\hline Cost of equity rate $\left(\mathrm{k}_{\mathrm{e}}\right)$ & $19,8 \%$ & $10,1 \%$ & $9,6 \%$ \\
\hline Long-term debt rate $\left(\mathrm{k}_{\mathrm{dl}}\right)$ & $14,2 \%$ & $6,9 \%$ & $6,7 \%$ \\
\hline Short-term debt rate $\left(\mathrm{k}_{\mathrm{ds}}\right)$ & $9,9 \%$ & $6,4 \%$ & $6,2 \%$ \\
\hline Cost of capital $(\mathrm{CC})$ & $15,7 \%$ & $8,2 \%$ & $7,8 \%$ \\
\hline Economic result of liquidity strategy & 3340 & $\mathbf{6 9 6 7}$ & 6457 \\
\hline
\end{tabular}

Source: hypothetical data.

In a similar way, we can calculate the values for a situation with a higher after-crisis cost of capital rates levels. The result is presented in table 4.

Table 4. Cost of capital and changes in economic results depending on the choice of liquidity investment strategy (after the crisis influence)

\begin{tabular}{|c|c|c|c|}
\hline Liquidity investment strategy & RES & MOD & FLX \\
\hline Cash Revenues (CR) & 1400 & 1456 & 1500 \\
\hline Fixed assets (FA) & 1120 & 1156 & 1184 \\
\hline Current assets (CA) & 420 & 655 & 900 \\
\hline Total assets $(\mathrm{TA})=$ Total liabilities $(\mathrm{TL})$ & 1540 & 1811 & 2083 \\
\hline Accounts payable (AP) & 210 & 328 & 450 \\
\hline Capital invested $\left(E+D_{1}+D_{s}\right)$ & 1330 & 1483 & 1634 \\
\hline Equity (E) & 798 & 890 & 980 \\
\hline Long-term debt $\left(\mathrm{D}_{1}\right)$ & 266 & 297 & 327 \\
\hline Short-term debt $\left(D_{s}\right)$ & 266 & 297 & 327 \\
\hline EBIT share in CR & 0,5 & 0,45 & 0,4 \\
\hline Earnings before interests and taxes (EBIT) & 700 & 655 & 600 \\
\hline Free Cash Flows in 1 to $n$ periods $\left(\mathrm{FCF}_{1 . . \mathrm{n}}\right)$ & 700 & 655 & 600 \\
\hline Initial Free Cash Flows in year $0\left(\mathrm{FCF}_{\mathrm{o}}\right)$ & -1330 & -1483 & -1634 \\
\hline $\mathrm{SZ}$ risk premium correction & 2 & 0,1 & 0,001 \\
\hline Leveraged and corrected risk coefficient $\beta_{l}$ & 2,8 & 1 & 0,93 \\
\hline Cost of equity rate $\left(\mathrm{k}_{\mathrm{e}}\right)$ & $47 \%$ & $20,3 \%$ & $18,9 \%$ \\
\hline
\end{tabular}


Table 4 continued

\begin{tabular}{|l|c|c|c|}
\hline \multicolumn{1}{|c|}{ Liquidity investment strategy } & RES & MOD & FLX \\
\hline Long-term debt rate $\left(\mathrm{k}_{\mathrm{dl}}\right)$ & $40 \%$ & $14,2 \%$ & $13,2 \%$ \\
\hline Short-term debt rate $\left(\mathrm{k}_{\mathrm{ds}}\right)$ & $27 \%$ & $12,5 \%$ & $11,8 \%$ \\
\hline Cost of capital $(\mathrm{CC})$ & $39 \%$ & $16,6 \%$ & $15,4 \%$ \\
\hline Economic result of liquidity strategy & 473 & $\mathbf{2 4 9 4}$ & 2269 \\
\hline
\end{tabular}

Source: hypothetical data.

\section{CONCLUSIONS}

Depending on a non-profit institution's business type, the sensibility to liquidity financing method risk might vary a lot. The character of a non-profit institution's mission also determines the best strategy which should be chosen. The best choice is the one with the adequate cost of financing and the highest economic result of liquidity strategy.

Figure 3. Model influence of the current assets investing strategy choice on the key performance indicators in a non-profit organization

\begin{tabular}{|c|c|c|}
\hline Restrictive & & Flexible \\
\hline & $\mathrm{CR}$ & $\nearrow$ \\
\hline$\triangle$ & $\mathrm{CF}$ & 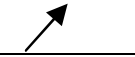 \\
\hline 2 & FCF & 3 \\
\hline$\nearrow$ & B & $\Delta$ \\
\hline$\nearrow$ & $\mathrm{CC}$ & \\
\hline$\nearrow \searrow \checkmark$ & NPO Performance & \\
\hline
\end{tabular}

where: NPO - non-profit institution

Source: own proposal.

This depends on the structure of financing costs. The lower the financing cost, the higher the effectiveness of non-profit institution activity measured by the economic result of liquidity strategy. An institution choosing between various solutions in liquidity needs to decide what level of risk is acceptable for its owners and capital suppliers. It was shown in the solutions presented 
in that paper. If the risk exposition is higher, a safer solution will be preferred. That choice results in consequences for the cost of financing. In this paper, we considered that the relation between risk and expected benefits from the liquidity decision and its effects on financing costs for a non-profit institution and an economic result of liquidity strategy.

Although liquid assets maintained in the non-profit institution are not a source of any special interests and although the close to cash assets together with credit lines available for non-profit institution are connected with resigning from realization of the part of incomes or costs, non-profit institutions could decide to maintain some liquidity reserves, not only because of transactional needs, but also from precautional and speculative reasons. Precautional liquidity results from a will to protect oneself against higher costs connected with impossible to predict negative economic events. It should be assessed from a safeguard's point of view. However, investment in liquid reserves resulting from speculative demand for money may be assessed by using a call option approach. In his paper, each of the above-mentioned aspects of liquidity was taken into consideration and presented. When considering option liquidity value, six factors with the biggest influence on it were pointed out. Further analysis of the liquidity value problem would aim at finding the credible methods of its determination. The non-profit institution liquidity value determination may often significantly contribute to the solution of working capital management problems.

\section{LITERATURE}

Baumol W.J. (1952), The Transactions Demand for Cash: An Inventory Theoretic Approach, "Quarterly Journal of Economics", No. 66.

Beck P.E. (1993), The Option Value of Money, Working Paper nr 93-15, November, Department of Economics, University of Delaware.

Beck P.E., Stockman D.R. (2005), Money as Real Options in a Cash-in-Advance Economy, "Economics Letters", Vol. 87.

Beranek W. (1963), Analysis for Financial Decisions, R.D. IRWIN, Homewood.

Berger P. (2008), Fundamentals of Health Care Financial Management, Wiley, New York..

Bougheas P., Mateut P., Mizen P. (2009), Corporate trade credit and inventories: New evidence of a trade-off from accounts payable and receivable, "Journal of Banking \& Finance", Vol. 33, No. 2.

Brigham E.F. (2006), Fiancial Management, http://www.swlearning.com/fi nance/brigham/theory11e/web_chapters/bri59689_ch30_web.pdf (April 2011).

Brigham E.F., Gapenski L.C. (2000), Zarzadzanie finansami, PWE, Warszawa.

Cote J.M., C.K. Latham, (1999), The Merchandising Ratio: A Comprehensive Measure of Working Capital Strategy, "Issues in Accounting Education", Vol. 14, No. 2. 
Emery G.W. (1988), Positive Theories of Trade Credit, Advances in Working Capital Management, "JAI Press", Vol. 1.

Fabozzi F.J. (1999), Investment Management, Prentice Hall, Upper Saddle River.

Fernandez P. (2008), Market Risk Premium Used in 2008 by Professors: A Survey with 1,400 Answers, http://ssrn.com/abstract=1344209 (April 16, 2009).

Fernandez P., Aguirreamalloa J., Avendaño L.C. (2011), Market Risk Premium Used in 56 Countries in 2011: A Survey with 6,014 Answers, http://ssrn.com/ab stract=1822182, (April 25, 2011).

Fernandez P., Del Campo B.J. (2010), Market Risk Premium Used in 2010 by Professors: A Survey with 1,500 Answers, http://ssrn.com/abstract=1606563, (May 13, 2010).

Gallinger G., Ifflander A.J. (1986), Monitoring Accounts Receivable Using Variance Analysis, "Financial Management", winter.

Henderson J.W., Maness T.P. (1989), The financial analyst's deskbook: A Cash flow approach to liquidity, Van Nostrand Reinhold, New York.

Hill N.C., Sartoris W.L. (1995), Short-Term Financial Management. Text and Casep, Prentice Hall, Englewood Cliffp.

Holmstrom B., Tirole J. (2001), LAPM: a liquidity-based asset pricing model, "Journal of Finance", Vol. 56.

Jaworski J. (2010), Teoria i praktyka zarządzania finansami przedsiębiorstw, CeDeWu, Warszawa.

Khoury N.T., Smith K.V, MacKay P.I. (1999), Comparing Working Capital Practices in Canada, the United States and Australia, "Revue Canadienne des Sciences de l'Administration", Vol. 16, No. 1.

Kim C-P., Mauer D.C., Sherman A.E. (1998), The Determinants of Corporate Liquidity: Theory and Evidence, "Journal of Financial and Quantitative Analysis", Vol. 33, No. 3.

Kim Y.H., Atkins J.C. (1978), Evaluating Investments in Accounts Receivable: A Wealth Maximizing Framework, "Journal of Finance", Vol. 33, No. 2.

Lane G.P., Longstreth E., Nixon V., (2001), A Community Leaders Guide to Hospital Finance, The Access project, Suite 2001.

Lee C.F., Finnerty J.E. (1990), Corporate finance. Theory, method and application, HBJ Publishers, San Diego.

Levy H., Gunthorpe D. (1999), Introduction do Investments, South-Western College Publishing, Cincinnati.

Lofthouse P. (2005), Investment Management, Wiley, Chichester.

Lyn E.O., Papaioannou G.J. (1996), Liquidity and the Financing Policy of the Firm: an Empirical Test, "Advances in Capital Management", Vol. 3.

McMenamin J. (1999), Financial Management - an introduction, Routledge, London.

Merton R.C., Perold A.F. (1999), Theory of Risk Capital in Financial Firms, [in:] D.H. Chew (ed.), The New Corporate Finance. Where Theory Meets Practice, McGraw-Hill, Boston.

Michalski G. (2004), Leksykon zarządzania finansami, C.H. Beck, Warszawa.

Michalski G. (2010), Strategiczne zarzadzanie ptynnościa finansowa $w$ przedsiębiorstwie, CeDeWu, Warszawa. 
Michalski G. (2011), Operating cycle and non-profit institutions efficiency, "Journal of academic research in economics", 3(3).

Michalski G. (2011b), Influence of the post-crisis situation on cost of capital and intrinsic liquidity value in non-profit organizations, "International journal of management and social sciences", Vol. 1(1).

Michalski G. (2011c), Efektywność inwestycji $w$ zapasy $w$ opodatkowanych i nieopodatkowanych organizacjach, [in:] D. Zarzecki (red.), Zarzadzanie finansami. Inwestycje, wycena przedsiębiorstw, zarządzanie wartościa, Zeszyty Naukowe, Uniwersytet Szczeciński nr 639, Szczecin.

Michalski G. (2012), Poziom zaangażowania kapitału $w$ zapasach $w$ organizacjach non-profit, [in:], D. Zarzecki (red.), Finanse, rynki finansowe, ubezpieczenia, „Zeszyty Naukowe Uniwersytetu Szczecińskiego”, nr 690.

Miller M.H., Orr D. (1966), A Model of the Demand for Money by Firms, "Quarterly Journal of Economics", No. 80.

Miller T.W., Stone B.K. (1996), The Value of Short-Term Cash Flow Forecasting Systems, "Advances in Working Capital Management", Vol. 3.

Mueller F.W., (1953), Corporate Working Capital and Liquidity, "The Journal of Business of the University of Chicago", Vol. 26, No. 3.

Myers P. C., Rajan R.G. (1998), The Paradox of Liquidity, "Quarterly Journal of Economics", Vol. 113, No. 3.

Nowicki M., (2004), The Financial Management of Hospitals and Healthcare Organizations, Health Administration Press, New York.

Opler T., Stulz R., Williamson R. (1999), The determinants and implications of corporate cash holdings, "Journal of Financial Economics", Vol. 52, No. 1.

Orlicky J. (1975), Material Requirements Planning, McGraw-Hill, New York.

Parrino R., Kidwell D.P. (2008), Fundamentals of Corporate Finance, Wiley, New York.

Peterson R., Silver E.A. (1979), Decision Systems for Inventory Management and Production Planning, Wiley, New York.

Plossl G.W. (1985), Production and Inventory Control, Principles and Techniques, Prentice Hall, Englewood Cliffs.

Poteshman A., Parrino R., Weisbach M. (2005), Measuring Investment Distortions when Risk-Averse Managers Decide Whether to Undertake Risky Project, "Financial Management", Vol. 34.

Puxty A.G., Dodds J.C. (1992), Financial Management Method and Meaning, Chapman and Hall, London.

Rast B. (2000), Household Liquidity - Why You Need It, "Business \& Economic Review", January-March.

Reilly F.K. (1992), Investments, The Dryden Press, Fort Worth.

Rzeczycka A. (2006), Zarządzanie środkami pieniężnymi w przedsiębiorstwie, [in:] G. Golawska-Witkowska, A. Rzeczycka, H. Zalewski (red.), Zarzadzanie Finansami Przedsiębiorstwa, OW Branta, Bydgoszcz.

Scherr F.C. (1989), Modern Working Capital Management, Prentice Hall, Englewood Cliffp.

Stone B.K., (1972), The Use of Forecasts and Smoothing in Control - Limit Models for Cash Management, "Financial Management". 
Tobin J. (1958), Liquidity Preference as Behavior Toward Risk, "Review of Economic Studies", No 25.

Washam J., Davis D. (1998), Evaluating Corporate Liquidity, “TMA Journal”, Vol. 18 , No. 2.

Zietlow J. (2010), Non-profit financial objectives and financial responses to a tough economy, "Journal of Corporate Treasury Management", Vol. 3, Nr 3.

Zietlow J., Hankin J.A., Seidner A.G. (2007), Financial Management for Non-profit Institutions, Wiley, New York. 